DOI: https://doi.org/10.31933/dijemss.v2i2 Received: 20 October 2020, Revised: 26 November 2020, Publish: 28 December 2020

\begin{tabular}{|c|c|c|}
\hline DINASTISTR & $\begin{array}{l}\text { DIJEMSS } \\
\text { DINASTI INTERNATIONAL JOURNAL } \\
\text { OF EDUCATION MANAGEMENT AND } \\
\text { SOCIAL SCIENCE }\end{array}$ & $\begin{array}{r}\text { https://dinastipub.org/DIJEMSS } \\
\text { editor@dinastipub.org } \\
08117401455\end{array}$ \\
\hline
\end{tabular}

THE IMPACT OF COMPENSATION, CAREER DEVELOPMENT AND WORK ENVIRONMENT TOWARDS Y GENERATIONS EMPLOYEE'S ORGANIZATIONAL COMMITMENT AT PT. BANGUN ANUGERAH HANJAYA

\author{
Riani Leviana Anggita Sari ${ }^{1}$, Irfan Noviandy Aulia ${ }^{2}$ \\ ${ }^{1)}$ Mercu Buana University, Jakarta, riani.lviana@gmail.com \\ ${ }^{2)}$ Mercu Buana University, Jakarta, irfan.noviandy@mercubuana.ac.id \\ Coresponding Author: Riani Leviana Anggita Sari
}

\begin{abstract}
This research aimed to analyze those impact which came from compensation, career development, and work environment towards organizational commitment of $Y$ generation employees at PT. Bangun Anugerah Hanjaya. This research type was included in quantitative research with sampling method used was simple random sampling. The population was all employees at PT. Bangun Anugerah Hanjaya with numbers of 137 people. Researchers used the Slovin formula in order to gather samples of 102 people. The analysis method used multiple linear regression. The results showed that compensation, career development, and work environment together (simultaneously) had a significant impact on employee organizational commitment. Partially, compensation, career development, and work environment had a significant positive impact on organizational commitment.
\end{abstract}

Keywords: Compensation, career development, work environment, organizational commitment.

\title{
INTRODUCTION
}

In this era, companies are facing various challenges, such as managing and maintaining the Y generation or millennials. According to the Ministry of Women's Empowerment and Child Protection and the Central Statistics Agency of the Republic of Indonesia (2018: 17)which said that the millennial generation is a generation which born between 1980 and 2000. Each generation has a different mindset, so do with Y generation. The advancement of technological era and the times made them more open-minded, creative, and potential. Y Generation has a lot of desires and achievements, making them tend to move from one company to another in a short period of time compared to previous generations. These $\mathrm{Y}$ generation conditions which move frequently assume that there is a problem with organizational commitment. 
Organizational commitment is a person's desire to maintain their membership and commit themselves to the company and strive to work optimally. Low organizational commitment will often replace the employee within the company. High employee turnover will cause many losses, such as increased costs, disrupted operations and others.

PT. Bangun Anugerah Hanjaya is a company that employs Y generation. The company was experiencing issues around organizational commitment. From these interviews results that were conducted with the company, it was revealed that so many employees had resigned. Based on the results of data recapitulation of employee turnover at PT. Bangun Anugerah Hanjaya it was obtained as follows:

Table 1. The Recapitulation of Employee TurnOver at PT. Bangun Anugerah Hanjaya

\begin{tabular}{cccc}
\hline Year & Total Employees & Resign Amount & \% Turnover \\
\hline 2016 & 80 & 9 & $11,25 \%$ \\
2017 & 110 & 13 & $11,82 \%$ \\
2018 & 145 & 18 & $12.41 \%$ \\
\hline Source: Human Resource Departement at PT. Bangun Anugerah Hanjaya
\end{tabular}

Table 1 shows that turnover continues to increase every year and explained if the turnover in the company was very high because the maximum number set by the company for turnover was 9\%. This issue has become concern that organizational commitment at PT. Bangun Anugerah Hanjaya decreased so the turnover in company would exceed the maximum stipulated by the company.

There are many factors that can affect organizational commitment that have been discussed in previous studies. Based on research by Njenga, Kamau, and Njenga (2015: 1), the factors that influence commitment are the work environment. Arta and Surya (2017: 1) reveal that organizational commitment can be affected by compensation. Meanwhile, Ramdhani, Ramdhani and Ainisyifa (2017: 1) said that organizational culture has an influence on organizational commitment. Younis, Akram and Naseeb (2013: 1) found that career development affects organizational commitment. Al Madi, Assal, Shrafat, and Zeglat (2017: 143) reveal that motivation can affect organizational commitment. Meanwhile, Hanasya (2016: 304) found that employee empowerment, group collaboration, and employee training have a positive influence on organizational commitment.

These factors were then used as pre-survey materials to follow these phenomena which occurred. Researchers then conducted a pre-survey at PT. Bangun Anugerah Hanjaya by distributing to 30 employees were include the $\mathrm{Y}$ generation, namely 19 to 39 years old to find out what are the dominant factors which cause those employees to survive or decide to resign from the company. According to the pre-survey, these following results were obtained:

Table 2. Pre-Survey which Factors that Affecting Organizational Commitment

\begin{tabular}{lc}
\hline \multicolumn{1}{c}{ Influencing Factors } & Percentage Result \\
\hline Work Environment & 86,7 \\
Compensation & 96,7 \\
Organizational Culture & 56,7 \\
Career Development & 93,3 \\
Motivation & 20
\end{tabular}


Employee Empowerment 23,3

Group Cooperation $\quad 33,3$

Employee Training $\quad 46,7$

Based on these pre-survey result, it was show that there were 3 factors which have the highest percentage, such as: 1) Compensation, 2) Career Development, 3) Work Environment. Based on these data, researchers conducted research with the title "The Impact of Compensation, Career Development and Work Environment towards Y Generations Employee's Organizational commitment at PT. Bangun Anugerah Hanjaya".

\section{LITERATURE REVIEW Compensation}

Compensation is the total of all gifts given to employees in return for their services (Mondy and Martocchio, 2016:234). Mondy and Martocchio (2016:247) divided this compensation into two forms, namely financial compensation and non-financial compensation. Financial compensation was divided into two forms, which is direct financial compensation and indirect financial compensation. Meanwhile, non-financial compensation was divided into two forms, namely non-financial the job (compensation related to work) and non-financial job environment (compensation related to the work environment).

\section{Career Development}

Career development is a vertical development which includes position, rank, education and assignments experienced by person in a series of staffing arrangements and used as a basis for payroll (Busro 2018:274). According to Busro (2018:281) career development was divided into three dimensions, such as improving the quality of performance, self-development and career clarity. Performance quality improvement was measured by 3 indicators, namely increased self-discipline, loyalty and increased motivation among employees. Meanwhile, selfdevelopment was measured by 4 indicators, such as the opportunity to take part in various trainings, the opportunity to continue education, the opportunity to attend various seminars/discussions / workshops, and the opportunity to take part in various competency courses to get expertise certificates. For career clarity, it was measured by 3 indicators, namely clear promotion, opportunity to become head/leader or deputy head/leader, and opportunity to occupy certain positions according to the existing of organizational structure.

\section{Work Environment}

The work environment is the whole stuff, tools and materials faced by the surrounding environment where they work, the work method both individually or in groups (Sedarmayanti, 2009:21). Sedarmayanti (2009:21) explained that the work environment was divided into two, namely the physical work environment and non-physical work environment. Indicators from physical work environment are work equipment, lighting or light, air temperature, job security. Indicators of non-physical work environment are employee relations with superiors, employee relationships with coworkers and work relationships with subordinates. 


\section{Organizational Commitment}

Meyer and Allen (Busro, 2018:82) explained that organizational commitment is a continuous behavior that person shows to the organization. Meyer and Allen (2001) in Busro (2018:78) revealed that there are three dimensions of organizational commitment, such as: affective commitment, continuance commitment and normative commitment. The indicators in affective commitment are strong trust and acceptance of organizational values and goals, loyalty to the organization and willingness to use efforts for the benefit of the organization. The indicators in the continuous commitment dimension were taking into account benefits by continuing to work in organization and calculating its losses if leaving this organization. Meanwhile, indicators in the normative commitment dimension are the willingness to work and responsibility in progressing the organization.

\section{Theoretical Framework and Hypothesis}

The research results which were conducted by Pratama and Aima (2018:366) explained that there is a significant relationship between compensation and organizational commitment. By providing appropriate compensation to employees it will be able to increase employee organizational commitment, various considerations should be made so the employees could receive appropriate compensation but should not harm the company as well. Handoko and Rambe (2018:40) in their research found that career development has a positive impact on organizational commitment. Employee organizational commitment will increase when there is career development carried out by the organization for employees, so the employee will feel ownership and loyalty to the organization which already provided opportunities for a career. Hanasya (2016:289) in her research found that the work environment has a significant positive connection towards organizational commitment. If work environment factors are well organized and a harmonious work environment was created (work relations between superiors and subordinates and work relationships among colleagues), it could be said that work environment is good and it would get impact for someone who works there and it will improve organizational commitment.

Based on previous research, it could be assumed that there is a partial or simultaneous connection between compensation, career development and work environment towards organizational commitment. The hypothesis and Theoretical framework in this research could be drawn as follows:

$\mathrm{H} 1$ : Compensation has a significant impact towards organizational commitment of $\mathrm{Y}$ generation employees at PT. Bangun Anugerah Hanjaya.

$\mathrm{H}$ 2: Career development has a significant influence on organizational commitment of $\mathrm{Y}$ generation employees at PT. Bangun anugerah Hanjaya.

H3: Work environment has a significant impact towards $\mathrm{Y}$ generation employees' organizational commitment at PT. Bangun anugerah Hanjaya.

H4: Compensation, career development and work environment have a significant effect on Y generation employees' organizational commitment at PT. Bangun anugerah Hanjaya. 


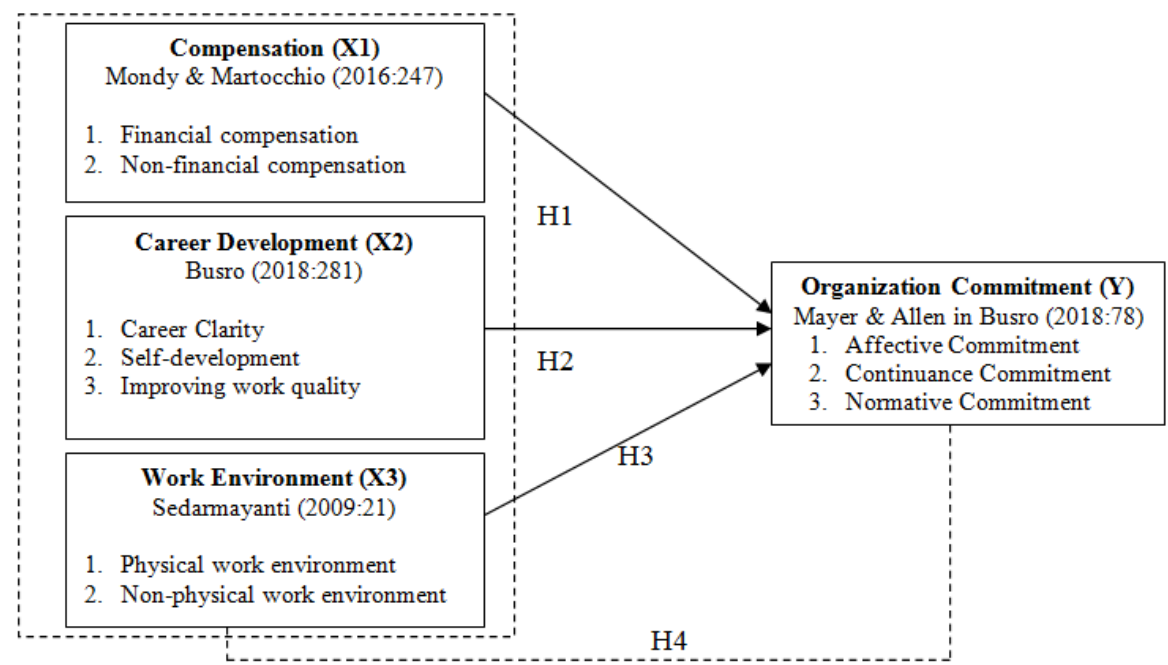

Figure 1. Theoretical Framework

\section{RESEARCH METHODS}

This research used a quantitative approach with an explanative or causal design. The independent variable in this research consists of compensation variable, career development variable and work environment variable, while the dependent variable was organizational commitment. The population in this research was all employees at PT. Bangun Anugerah Hanjaya, with numbered of 137 people. Researchers used probability sampling with the type of simple random sampling. The sample used was 102 respondents (Slovin, error tolerance 5\%). The data analysis method used by multiple linear regression models with the assistance of SPSS version 25.00 program to examine those research hypothesis.

\section{RESULTS AND DISCUSSION Validity and Reliability Test}

Based on these validity test result, it shows that all questionnaire items for all research variables were declared valid, because $r$ count $>r$ table.

Table 3. Validity Test Results

\begin{tabular}{|c|c|c|c|c|c|c|c|c|c|c|c|c|}
\hline No. & $\mathrm{r}_{\text {count }} \mathrm{X}_{1}$ & $r_{\text {table }}$ & Info & $\mathrm{r}_{\text {count }} \mathrm{X}_{2}$ & $\mathrm{r}_{\text {table }}$ & Info & $\mathrm{r}_{\text {count }} \mathrm{X}_{3}$ & $r_{\text {table }}$ & Info & $\mathrm{r}_{\text {count }} \mathrm{Y}$ & $\mathrm{r}_{\text {table }}$ & Info \\
\hline 1 & $.448 * *$ & 0.195 & Valid & $.485 * *$ & 0.195 & Valid & $.651 * *$ & 0.195 & Valid & $.466 * *$ & 0.195 & Valid \\
\hline 2 & $.368 * *$ & 0.195 & Valid & $.693 * *$ & 0.195 & Valid & $.618 * *$ & 0.195 & Valid & $.560 * *$ & 0.195 & Valid \\
\hline 3 & $.391 * *$ & 0.195 & Valid & $.792 * *$ & 0.195 & Valid & $.615 * *$ & 0.195 & Valid & $.645^{* *}$ & 0.195 & Valid \\
\hline 4 & $.474 * *$ & 0.195 & Valid & $.835 * *$ & 0.195 & Valid & $.695 * *$ & 0.195 & Valid & $.616 * *$ & 0.195 & Valid \\
\hline 5 & $.457 * *$ & 0.195 & Valid & $.791 * *$ & 0.195 & Valid & $.660 * *$ & 0.195 & Valid & $.627 * *$ & 0.195 & Valid \\
\hline 6 & $.526 * *$ & 0.195 & Valid & $.714 * *$ & 0.195 & Valid & $.685^{* *}$ & 0.195 & Valid & $.695^{* *}$ & 0.195 & Valid \\
\hline 7 & $.487 * *$ & 0.195 & Valid & $.723 * *$ & 0.195 & Valid & $.637 * *$ & 0.195 & Valid & $.414 * *$ & 0.195 & Valid \\
\hline 8 & $.622 * *$ & 0.195 & Valid & $.738 * *$ & 0.195 & Valid & $.681 * *$ & 0.195 & Valid & $.431 * *$ & 0.195 & Valid \\
\hline 9 & $.657 * *$ & 0.195 & Valid & $.749 * *$ & 0.195 & Valid & $.640 * *$ & 0.195 & Valid & $.330 * *$ & 0.195 & Valid \\
\hline 10 & $.671^{* *}$ & 0.195 & Valid & $.770 * *$ & 0.195 & Valid & $.534 * *$ & 0.195 & Valid & $.401 * *$ & 0.195 & Valid \\
\hline 11 & $.614 * *$ & 0.195 & Valid & & & & & & & $.210 *$ & 0.195 & Valid \\
\hline
\end{tabular}


Based on these reliability test result, it could be seen that compensation variable (X1), career development (X2), work environment (X3) and organizational commitment variable (Y) were declared reliable because they have a Cronbach's Alpha value above 0.6.

Table 4. Reliability Test Results

\begin{tabular}{lccc}
\hline \multicolumn{1}{c}{ Variable } & Cronbach's Alpha & Terms & Information \\
\hline Compesation & 0.728 & $>0.6$ & Reliable \\
\hline Career Development & 0.773 & $>0.6$ & Reliable \\
\hline Work Environment & 0.756 & $>0.6$ & Reliable \\
\hline Organizational Commitment & 0.720 & $>0.6$ & Reliable \\
\hline
\end{tabular}

\section{Classic Assumption Test}

According to these normality test result, the Sig. of these four variables above more than 0.05 , thus the Kolomogorov-Smirnov test results of these four variables above met the normality requirements with the Sig. $>\alpha=0.05$. This, it can be defined that the data tested has a normal data distribution.

Table 5. Data Normality Test Results

\begin{tabular}{|c|c|c|c|c|c|}
\hline \multicolumn{6}{|c|}{ One-Sample Kolmogorov-Smirnov Test } \\
\hline & & Compensation & $\begin{array}{c}\text { Career } \\
\text { Development }\end{array}$ & $\begin{array}{c}\text { Work } \\
\text { Environment }\end{array}$ & $\begin{array}{c}\text { Organizational } \\
\text { Commitment }\end{array}$ \\
\hline \multicolumn{2}{|l|}{$\mathrm{N}$} & 102 & 102 & 102 & 102 \\
\hline \multirow[t]{2}{*}{$\begin{array}{l}\text { Normal } \\
\text { Parameters }^{\mathrm{a}, \mathrm{b}} \\
\end{array}$} & Mean & 3,461 & 3,473 & 3,395 & 3,685 \\
\hline & $\begin{array}{l}\text { Std. } \\
\text { Deviation }\end{array}$ & 0,440 & 0,616 & 0,600 & 0,295 \\
\hline \multicolumn{2}{|l|}{ Test Statistic } & $\mathbf{0 , 0 8 7}$ & $\mathbf{0 , 0 7 9}$ & $\mathbf{0 , 0 7 5}$ & $\mathbf{0 , 0 3 9}$ \\
\hline \multicolumn{2}{|c|}{ Asymp. Sig. (2-tailed) } & $.053^{\mathrm{c}}$ & $.124^{\mathrm{c}}$ &. $\mathbf{1 8 5}^{\mathrm{c}}$ & $.200^{\mathrm{c}, \mathrm{d}}$ \\
\hline
\end{tabular}

a. Test distribution is Normal.

b. Calculated from data.

c. Lilliefors Significance Correction.

Based on these multicollinearity test results, the VIF value of each variable was less than 10. This, it could be concluded that the data tested did not occur multicollinearity.

Table 6. Multicollinearity Test Results

\begin{tabular}{lcrr}
\hline & \multicolumn{2}{c}{ Coefficients $^{\mathbf{a}}$} & \\
\hline & \multirow{2}{*}{ Model } & \multicolumn{2}{c}{ Collinearity Statistics } \\
\cline { 2 - 3 } & & & Tolerance \\
\hline (Constant) & 0.688 & \multicolumn{1}{c}{ VIF } \\
\hline Compensation & 0.663 & 1.453 \\
\hline Career Development & 0.690 & 1.449 \\
\hline Work Environment &
\end{tabular}

a. Dependent Variable: Organizational Commitment 
Based on the results of the heteroscedasticity test, it can be seen that there is no clear pattern such as the dots widening above and below the 0 on the $\mathrm{Y}$ axis, so the dots spread randomly and did not form a certain pattern. This, it can be concluded that the data tested did not occur heteroscedasticity, so the regression model was feasible to use.

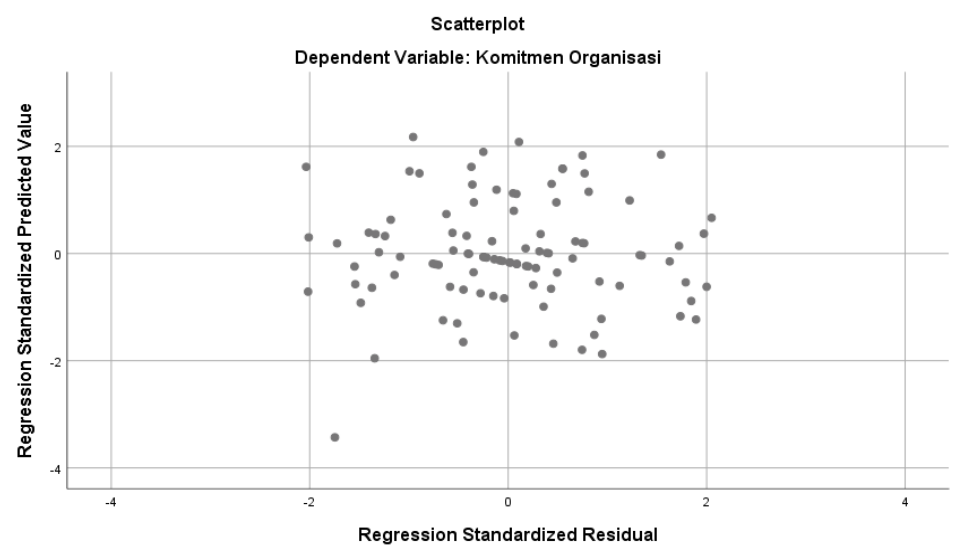

Figure 2. Heteroscedasticity Test Results

\section{Hypothesis Test}

This analysis produces has structure type equation that explains the relationship between compensation variables, career development, and work environment towards organizational commitment. This test is performed by the coefficient of determination, $\mathrm{t}$ test and $\mathrm{F}$ test. The results of this test were described in Table 7 below.

Table 7. Hypothesis Test Results

\begin{tabular}{|c|c|c|c|c|}
\hline \multicolumn{5}{|c|}{ Coefficients $^{\mathrm{a}}$} \\
\hline \multirow{2}{*}{ Model } & \multicolumn{2}{|c|}{ Unstandardized Coefficients } & \multirow{2}{*}{$\mathrm{t}$} & \multirow{2}{*}{ Sig. } \\
\hline & $\mathrm{B}$ & Std. Error & & \\
\hline (Constant) & 1.505 & 0.090 & 16.743 & 0.000 \\
\hline Compesation & 0.268 & 0.030 & 9.061 & 0.000 \\
\hline Career Development & 0.191 & 0.021 & 8.871 & 0.000 \\
\hline Work Environment & 0.174 & 0.022 & 8.061 & 0.000 \\
\hline $\mathrm{F}$ & & & 218.090 & $.000^{\mathrm{b}}$ \\
\hline Adjusted $\mathrm{R}^{2}$ & & & 0.866 & \\
\hline
\end{tabular}

Based on Table 7 above, it could be seen that the t-count of compensation variable is $9,061>1.98$, the t-count of career development was 8,871>1.98 and the t-count of work environment variable was $8,061>1.98$, it could be said that both compensation variable, career development variable, work environment have an impact towards organizational commitment with the value of Sig. of the independent variables $<0.05$ which means significant, meaning that $\mathrm{H} 1, \mathrm{H} 2$, and $\mathrm{H} 3$ were accepted. The regression equation could be drawn as follows:

$$
Y=1,505+0,268 X_{1}+0,191 X_{2}+0,174 X_{3}+e
$$

The $\mathrm{F}$ test result and $\mathrm{R}^{2}$ test show that have F-count value of $218.09>\mathrm{F}$-table and Sig. 0.000, due to the Sig. 0,000 < Sig. 0.05 then the hypothesis $(\mathrm{H} 4)$ was accepted which defined that compensation, career development, and work environment simultaneously affect 
organizational commitment by $86.6 \%$ while the remaining $13.4 \%$ was influenced by other factors outside of this research.

\section{Inter-Dimensional Correlation Analysis}

According to inter-dimensional correlation matrix test result, the greatest dimensional correlation value in the compensation dimension was financial compensation. For the value of the greatest dimension correlation in the dimension of career development was career clarity. Meanwhile, the greatest correlation value for the dimensions of the work environment was the non-physical work environment.

Table 8 Inter-Dimensional Correlation Results

\begin{tabular}{|c|c|c|c|c|}
\hline \multirow[b]{3}{*}{ Variabel } & \multicolumn{4}{|c|}{ Correlations } \\
\hline & \multirow[b]{2}{*}{ Dimension } & \multicolumn{3}{|c|}{ Organizational Commitment (Y) } \\
\hline & & $\begin{array}{c}\text { Affective } \\
\text { Commitment }\end{array}$ & $\begin{array}{l}\text { Continuance } \\
\text { Commitment }\end{array}$ & $\begin{array}{c}\text { Normative } \\
\text { Commitment }\end{array}$ \\
\hline \multirow{2}{*}{$\begin{array}{l}\text { Compensation } \\
\text { (X1) }\end{array}$} & Financial Compensation & $0.717^{* *}$ & $0.300^{* *}$ & 0.166 \\
\hline & Non-financial Compensation & $0.574^{* *}$ & $0.288^{* *}$ & $0.246^{*}$ \\
\hline \multirow{3}{*}{$\begin{array}{c}\text { Career } \\
\text { Development } \\
\text { (X2) }\end{array}$} & Career Clarity & $0.564^{* * *}$ & $0.405^{* *}$ & $0.273^{* *}$ \\
\hline & Self-development & $0.625^{* * 4}$ & $0.345^{\text {** }}$ & $0.315^{* *}$ \\
\hline & Improving Work Quality & $0.681 * *$ & $0.318^{* *}$ & $0.389^{* *}$ \\
\hline \multirow{2}{*}{$\begin{array}{c}\text { Work } \\
\text { Environment } \\
\text { (X3) }\end{array}$} & Physical Work Environment & $0.674^{* *}$ & $0.290^{* *}$ & $0.222^{*}$ \\
\hline & Non-physical Work Environment & $0.676^{* *}$ & $0.272^{* *}$ & $0.327^{* *}$ \\
\hline
\end{tabular}

**. Correlation is significant at the 0.01 level (2-tailed).

*. Correlation is significant at the 0.05 level (2-tailed).

\section{CONCLUSION AND SUGGESTION Conclusion}

Conclusion Based on these research results and discussion in previous chapters, There are several conclusions could be made as follows:

1) Compensation has a positive and significant impact on Employee Organizational Commitment, with the financial compensation dimension having the strongest influence on affective commitment dimension.

2) Career Development has a positive and significant impact on Employee Organizational Commitment, with the dimension of improving work quality having the strongest influence towards the dimension of affective commitment.

3) Work Environment has a positive and significant influence over Employee Organizational Commitment, with non-physical work environment dimension having the strongest influence towards the affective commitment dimension.

4) Compensation, Career Development and Work Environment together have a significant effect on Employee Organizational Commitment.

\section{Suggestion}

Based on these discussion analysis result and some of the conclusions above, the suggestions that could be given as complement to the results of this research are as follows: 


\section{For Agencies}

The results showed that compensation has a very significant influence over employee organizational commitment with the dimension of financial compensation as the most dominant dimension in relation to organizational commitment. For this reason, researchers provide suggestions based on level / position to agencies to do these following advise:

1) For the Helper position, companies can do several ways, such as:

a) Applying salary based on workload and employee work hours and evaluating compensation management regularly.

b) Provide health and employment insurance facilities.

c) Provide meals allowance/food voucher.

2) For the operator position, the company can do several ways, namely:

a) Applying salaries based on employee workload, employee working hours and similar industry payroll standards and evaluating compensation management regularly

b) Provide health and employment insurance facilities.

c) Provide meals allowance / food voucher

d) Giving wholesale premium, skills allowance and overtime pay.

3) For the Job Captain position, companies can do several ways, namely:

a) Applying salary based on employee workload, and evaluating compensation management regularly

b) Provide health and employment insurance facilities.

c) Provide meals allowance / food voucher

d) Implementing job allowances and production incentives.

4) For the Admin position, the company can do several stuff, such as :

a) Applying salary system based on the position and workload of employees and evaluate compensation management regularly.

b) Provide health and employment insurance facilities.

c) Applying an overtime pay system.

d) Give some extra leave.

e) Provides allowances based on division/department.

5) For staff positions, companies could do several ways, namely:

a) Applying salary system based on position, division/department and employee workload and evaluating compensation management regularly

b) Providing public and private health insurance and employment facilities.

c) Provide food and transport allowances.

d) Awarding services or dedication bonuses.

e) Providing incentives based on KPI.

6) For a Supervisor position, a company can do several ways, like:

a) Implementing salary system based on position, workload and division / department.

b) Providing public and private health insurance and employment facilities.

c) Provide transport allowances, birth allowances, non-formal education allowances (seminars and basic training), occupational allowances and cooperative facilities.

d) Provide bonuses and local vacation packages throughout Indonesian region.

7) For the Division Head position, the company can do several ways, such as:

a) Implement salary system based on position, workload and scope of responsibility as well as periodically evaluate compensation management. 
b) Providing public and private health insurance and employment facilities with nominal adjustments from grade and providing birth allowances.

c) Provide bonuses and vacation packages throughout Southeast Asia region.

d) Provide family allowances, non-formal education allowances (skills training), transport / vehicle allowances, educational allowances for children up to high school and cooperative facilities.

8) For the Manager position, the company can do several ways, such as :

a) Applying salary system based on position /position and scope of responsibility and periodically evaluating compensation management.

b) Providing public and private health insurance and employment facilities with nominal adjustments from grade and providing birth allowances.

c) Providing family allowances, vehicle allowances, house allowances, non-formal education allowances (competency and skills training), formal education allowances, educational allowances for children up to Bachelor degree and cooperative facilities.

d) Providing bonuses, holiday packages throughout Asian region or religious tour packages.

The results showed that career development had a significant influence on employee organizational commitment with the dimension of career clarity as the most dominant dimension that related to organizational commitment. For this reason, the researchers provide suggestions based on level / position on agencies to do these following actions:

a) For the helper position, the company could arrange a career path regarding contract status which adjusted to the performance evaluation result and productivity levels.

b) For the operator position, the company could arrange a career path regarding the contract status which will be adjusted to the performance results and the production scheme result.

c) For the captain position, companies need to prepare a career path regarding contract status which will be adjusted to the evaluation of group performance results.

d) For admin positions, the company give an offers to employee contract status and staff positions which will be adjusted on tenure of performance evaluation results, competencies and qualifications.

e) For staff positions, the company evaluates the status of employee work contracts and offerred supervisory positions which will be adjusted to special assignments (psychological tests, interviews with division heads / managers) performance and competency evaluation and acting (special assignments).

f) For the position of Head of Division and Manager, companies could carry out promotions / job transfers or grade increases based on the results of competency evaluation, specifics psychological tests and evaluation of performance results.

The results showed that work environment had a significant impact towards employee organizational commitment with the dimension of non-physical work environment as the most dominant dimension which related to organizational commitment. For this reason, the researchers provided suggestions to agencies to do these following actions such as:

a) Every position of head / leader, conducts regular coaching once a month for the staff.

b) HR carries out a counseling program for employees.

c) Companies hold family gathering / outbound programs for employees.

d) The company holds special activities such as morning talks, meals together or special activities such as halal bi halal, Christmas, or commemoration of independence day and other activities. 


\section{For Further Researchers}

The authors wishes that further research could dig deeper related to other variables such as organizational culture, employee training and work motivation which affect the organizational commitment according to the pre-research survey, such as the high impact of compensation on organizational commitment which found in this research were opens the possibility of having other impact towards other variables.

\section{REFERENCES}

Al Madi, F. N., Assal, H., Sharafat, F., dan Zeglat, D. (2017). The Impact of Employee Motivation on Organizational Commitment. Europian Journal of Business and Management, 9(15), 134-145.

Arta, I.G.N.W. dan Surya, I. B. K. (2017). Pengaruh Kompensasi Terhadap Komitmen Organisasional Dan Turnover Intention Pada Agent Pru Megas. E-Jurnal Manajemen Unud, 6(8), 4156-4184.

Badan Pusat Statistik Republik Indonesia. (2018). Profil Generasi Milenial Indonesia. Kementerian Pemberdayaan Perempuan dan Perlindungan Anak. Jakarta.

Busro, M. (2018). Teori-teori Manajemen Sumber Daya Manusia. Prenadamedia Group. Jakarta.

Handoko, D. S. dan Rambe, M. F. (2018). Pengaruh Pengembangan Karir dan Kompensasi terhadap Komitmen Organisasi Melalui Kepuasan Kerja. Maneggio: Jurnal Ilmiah Magister Manajemen, 1(1), 31-45.

Hanasya, J. (2016). Testing the Effects of Employee Engagement, Work Environment, and Organizational Learning on Organizational Commitment. Prodecia-Social and Behavioral Sciences, 229: 289-297.

Hanasya, J. (2016). Examining the Effects of Employee Empowerment, Teamwork, and Employee Training on Organizational Commitment. Prodecia-Social and Behavioral Sciences, 229: 289-306.

Mondy, R. W. dan Martocchio, J. J. (2016). Human Resource Management, Fourteenth Edition, Global Edition. Pearson Education Limited. Lomdon.

Njenga, G., Kamau, C., dan Njenga, S. (2015). Factors Affecting Employees' Commitment to an Organization: A Case Study of Jodan College of Technology (JCT), Thika. International Journal of Scientific and Research Publications, 5: 1-7.

Ramdhani, A. Ramdhani, M. A., dan Ainisyifa, Hilda. (2017). Conceptual Framework of Corporate Culture Influenced on Employees Commitment to Organization. International Business Management, 11: 826-830.

Sedarmayanti. (2009). Sumber Daya Manusia dan Produktivitas Kerja. Mandar Maju. Bandung.

Pratama, R. dan Aima, M. H. (2018). The Effect of Compensation And Employee Engagement on Organizational Commitments and Its Implementation Toward Employee's Performance Of Pt Xyz Jakarta. International Journal of Scientific and Research Publications, 8: 360-368. 
Younis, N., Akram, A., dan Naseeb, R. A. K. (2013). Career Development and Organizational Commitment: Case study of a Pharmaceutical Organization in United Kingdom. International Journal of Scientific and Research Publications, 3: 1-4. 